\title{
Isoflavones: Anti-Inflammatory Benefit and Possible Caveats
}

\author{
Jie Yu, Xiaojuan Bi, Bing Yu and Daiwen Chen * \\ Animal Nutrition Institute, Sichuan Agricultural University, Chengdu 611130, China; yujie@sicau.edu.cn (J.Y.); \\ zsjg214@163.com (X.B.); ybingtian@163.com (B.Y.) \\ * Correspondence: dwchen@sicau.edu.cn; Tel./Fax: +86-835-288-2088
}

Received: 26 February 2016; Accepted: 2 June 2016; Published: 10 June 2016

\begin{abstract}
Inflammation, a biological response of body tissues to harmful stimuli, is also known to be involved in a host of diseases, such as obesity, atherosclerosis, rheumatoid arthritis, and even cancer. Isoflavones are a class of flavonoids that exhibit antioxidant, anticancer, antimicrobial, and anti-inflammatory properties. Increasing evidence has highlighted the potential for isoflavones to prevent the chronic diseases in which inflammation plays a key role, though the underlying mechanisms remain unclear. Recently, some studies have raised concerns about isoflavones induced negative effects like carcinogenesis, thymic involution, and immunosuppression. Therefore, this review aims to summarize the anti-inflammatory effects of isoflavones, unravel the underlying mechanisms, and present the potential health risks.
\end{abstract}

Keywords: isoflavones; anti-inflammation; health risks; flavonoids

\section{Introduction}

Inflammation is a biological response stimulated by pathogens, damaged cells, or irritants. Basically, inflammation is an orchestrated protective process to resolve infection, clear out necrotic cells, and trigger tissue repair [1]. However, this process must be rapid, destructive, specific, and well-controlled in order to avoid the over activation of innate immune response, chronic infectious, and/or inflammatory disorders which may cause serious tissue damage [2]. Solid evidence has shown that the development of various diseases including obesity, diabetes, metabolic syndrome, atherosclerosis, rheumatoid arthritis, and cancer are strongly correlated with inflammation [3-7].

Though steroidal or non-steroidal anti-inflammatory drugs are currently used to treat inflammation, these drugs are usually accompanied with unexpected side effects, and also, they are not considered as a good clinical choice for chronic inflammatory disorders [8]. As such, it is urgent to find an effective and safe anti-inflammatory therapy. Numerous epidemiological studies have indicated that vegetarian diets based on fruit and vegetable consumption are beneficial for human health [9-11], but the involved food components and the underlying mechanisms still remain unclear. Chinese traditional medicine has had a long history of applying crude plant extracts to treat diseases and disorders exemplified by acute and chronic inflammation [12-14]. Recent investigations have demonstrated that the polyphenols from plant sources, in particular flavonoids, exhibit anti-inflammatory activity both in vitro and in vivo [14-17]. This not only provides an explanation for the health benefit of vegetarian diets and Chinese medicine, but also identifies potential agents for treating inflammatory disorders, including possible therapy for life-threatening diseases.

Flavonoids, which include over 6000 identified family members, are a group of phenolic compounds that are widely distributed in plants and fungus. They have been well-known for their antioxidant, antimicrobial, and anti-inflammatory health benefits $[2,18,19]$. Within this family, the focus of research has been on a subclass, isoflavones, which are mainly found in soy beans, soy foods, and legumes [20-24] (Table 1). It is well-known that isoflavones act as phytoestrogens 
to exert pseudohormonal activity by binding to estrogen receptors (ER) in mammals [25,26], and also possess antioxidant, anticancer, antimicrobial, and anti-inflammatory activities just like other flavonoids [27-30]. Daidzein and genistein are the most common isoflavones, whose characteristic chemical structure (B-ring is linked to the C3 position of the C-ring instead of the C2 position) resembles the structure of estrogens, in particular 17- $\beta$ estradiol [21] (Figure 1). As such, isoflavones elicit either a weak estrogenic (agonistic) or anti-estrogenic (antagonistic) effect, depending on the levels of endogenous estrogens and ER [31]. Isoflavones block the binding of more potent estrogens, potentially playing a role in preventing hormone-related cancer like breast cancer, cervical cancer, and the male prostate or testicular cancer [32]. Interestingly, the incidence of breast and prostate cancers is lower among Asians in comparison to people in the Western world [33], and this could be related to the significantly different consumption of isoflavones in Asian diets (15-47 mg/day) compared with Western diets (0.15-1.7 mg/day) [34,35].

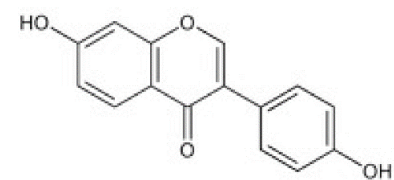

Daidzein

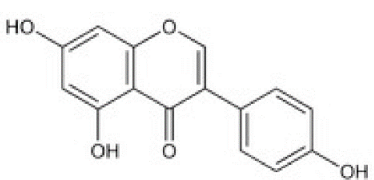

Genistein

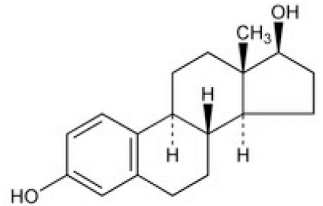

Estradiol

Figure 1. Structure of isoflavones and estradiol.

Table 1. Approximate content of isoflavones in main sources.

\begin{tabular}{ccc}
\hline Sources & Approximate Contents $\mathbf{( m g / 1 0 0 ~ g ) ~}$ & Reference \\
\hline Soy bean & $26-381$ & {$[20,22]$} \\
Roasted soy bean & 246 & {$[23]$} \\
Soy tempe & 148 & {$[23]$} \\
Soy flour & $83-466$ & {$[22,23]$} \\
Tofu & $8-67$ & {$[20,22]$} \\
Miso & $25-89$ & {$[22]$} \\
Tempeh & 86.5 & {$[20]$} \\
\hline
\end{tabular}

The physiological effects of flavonoids depend on their bioavailability. Isoflavones are the most absorbable and bioavailable flavonoids, and the bioavailability of genistein is greater than that of daidzein [36,37]. After ingestion, isoflavone glucosides are hydrolyzed to aglycones by glucosidases in the small intestine, where the metabolites are absorbed completely in part or further metabolized into other metabolites, such as equol and $O$-desmethylangolensin, by intestinal microflora in the large intestine $[34,38,39]$. Next, the metabolites enter the portal vein and undergo further metabolism in the liver [40]. Isoflavones persist in plasma for about $24 \mathrm{~h}$ and the average half-life is $6-8 \mathrm{~h}$, as previously reported [41].

Recently, increasing reports about the inhibition of inflammation by isoflavone are available. Meanwhile, some studies have raised concerns that isoflavones induced negative effects like carcinogenesis, thymus atrophy, and immune system abnormalities. Therefore, in this work, we reviewed the anti-inflammatory effects of isoflavones, unraveled the underlying mechanisms, and presented the potential health risks. This document provides some supporting knowledge of fruit and vegetable consumption, and encourages the application of natural medicine.

\section{Isoflavones and Anti-Inflammatory Effects}

In recent decades, extensive epidemiological studies, together with in vivo and in vitro experiments, have indicated that isoflavones are beneficial for patients with cardiovascular diseases, cancer, osteoporosis, and/or postmenopausal [27,42,43]. Isoflavones were originally speculated to act as an anti-inflammatory agent because genistein down-regulates cytokine-induced signal transduction 
events in the cells of the immune system [44]. Thereafter, an increasing number of investigations have consistently proven that isoflavones exhibit anti-inflammatory functions.

In mouse models, isoflavone genistein exerts anti-inflammatory properties affecting granulocytes, monocytes, and lymphocytes [44]. Isoflavone-containing diets prevent the inflammation-associated induction of metallothionein in the intestine, and the induction of manganese superoxide dismutase (Mn-SOD) in the liver of mice injected with endotoxin lipopolysaccaride (LPS), and suppresses the intestinal response to inflammation by modulating the action of pro-inflammatory cytokine interleukin (IL)-6 [45]. Kao et al. processed soybean cake, a byproduct of the soybean oil industry, into powder in their experiment [46]. They found that the isoflavone powders and genistein standard effectively inhibit LPS-induced inflammation, reduce leukocyte numbers in mouse blood, and lower the production of IL-1 $\beta$, IL-6, nitric oxide (NO), and prostaglandin E $2\left(\mathrm{PGE}_{2}\right)$ in both peritoneal exudates cell supernatant and peritoneal exudates fluid [46]. Soybean methanolic fraction containing isoflavones possess anti-inflammatory activity in the experimental inflammation model of croton oil-induced ear oedema [47]. The unique isoflavone, puerarin can protect the brain from ischemic damage after middle cerebral artery occlusion in rats, and this effect is attributable to the anti-inflammatory properties of puerarin by inhibiting cyclooxygenase-2 (COX-2) expression in astrocyte and microglia [48]. Recently, genistein pre-treatment has been shown to reduce NO and $\mathrm{PGE}_{2}$, and suppress the production of D-galactosamine-induced proinflammatory cytokines, including tumor necrosis factor- $\alpha$ (TNF- $\alpha$ ) and IL-1 $\beta$ in male Wistar rats [49]. In another study using a guinea pig model of asthma, genistein has been shown to significantly inhibit ovalbumin-induced acute bronchoconstriction, reduce ovalbumin-induced pulmonary eosinophilia and eosinophil peroxidase activity, and attenuate ovalbumin-induced airway hyperresponsiveness to inhaled methacholine [50]. These in vivo findings indicate that various isoflavones consistently show anti-inflammatory effects in multiple animal models, while in vitro studies using different cultured cells have also demonstrated the anti-inflammatory activity of isoflavones.

In primary cultures of human chondrocytes, genistein pretreatment reduces the LPS-stimulated COX-2 protein level and NO in supernatant without affecting COX-1 protein levels [51]. The genistein suppression of COX-2, but not COX-1, is advantageous since suppressing COX-2 can reduce the production of proinflammatory molecules [51]. Isoflavone daidzein prevents TNF- $\alpha$-induced increases in pro-inflammatory chemokine Cxcl2 expression and activity, and markedly inhibits TNF- $\alpha$-induced protein poly-adenosine diphosphate-ribosylation in murine lung epithelial cells [52]. In human monocyte THP-1 cells, daidzein suppresses the LPS-induced IL-6, IL-12, and TNF- $\alpha$ expression levels [53]. Most recently, an investigation reported that genistein prevents homocysteine-induced vascular endothelial cell death, the changes of cell morphology, and the production of reactive oxygen species (ROS), thereby suggesting endothelial cell inflammatory injury is blocked by genistein [54].

In human trials, eight weeks of consuming a soy nut diet $(340 \mathrm{mg}$ isoflavones/100 $\mathrm{g}$ soy nut) has been shown to reduce the markers of inflammation (e.g., IL-18 and C-reactive protein) and increase plasma nitric oxide levels in postmenopausal women with metabolic syndrome [55]. In postmenopausal women with hypertension, dietary soy nuts $(25 \mathrm{~g}$ soy protein and $101 \mathrm{mg}$ aglycone isoflavones) improve endothelial function and the underlying inflammatory process [56]. Isoflavone-rich soy foods also decrease serum levels of $\mathrm{C}$-reactive protein in end-stage renal failure patients and interferon $\gamma$ (IFN- $\gamma$ ) concentrations in healthy volunteers [57,58]. A validated food frequency questionnaire suggests that soy food consumption is related to lower circulating levels of IL-6, TNF $\alpha$, and soluble TNF receptors 1 and 2 in Chinese women [59]. However, another study indicates that soy protein and isoflavone (either alone or together) have no impact on serum lipids or inflammatory markers, and the reason might be that healthy late postmenopausal women lack the ability to produce equol, which is a metabolite of isoflavones and has more effective biological and pharmacological effects than its prototype [60]. Similar results also indicate that cardiovascular risk reduction with soy nuts is not uniform and may be dependent on the ability to produce equol [61]. 
The anti-inflammatory properties of isoflavones have been addressed in animals, cell cultures, and clinical trials (Table 2). Moreover, a large number of studies have also elucidated the underlying mechanisms. Though the mechanisms explaining the anti-inflammatory effects of isoflavones still remain unclear, several possibilities have been well unraveled.

Table 2. In vivo and in vitro anti-inflammatory effects of isoflavones.

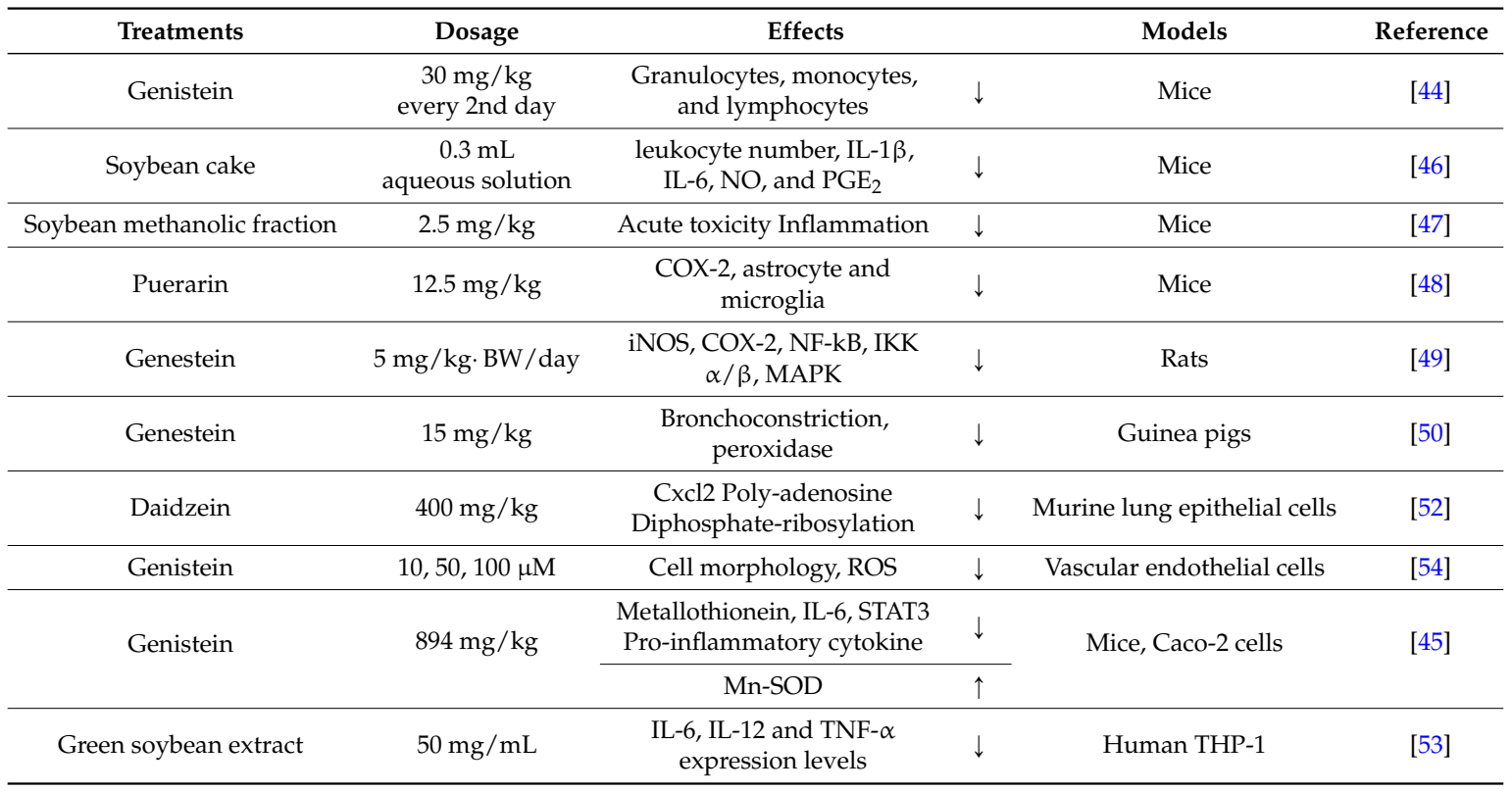

\section{Anti-Inflammatory Mechanisms of Isoflavones}

\subsection{Antioxidative Activities}

Free radicals and ROS are produced during normal oxygen metabolism or the physiological process stimulated by exogenous factors, like phagocytosis [62,63]. Excess free radicals and ROS may induce detrimental reactions such as peroxidation of membrane lipids, oxidative damage to nucleic acids and carbohydrates, and oxidation of the susceptible groups in proteins $[2,64,65]$. Typically, ROS induces the release of various inflammatory mediators, some of which attract neutrophils and other inflammatory cells to promote inflammation and tissue damage $[2,66]$. Isoflavones are known to directly scavenge reactive species generated by human neutrophils $[67,68]$.

Isoflavones are scavengers of a wide range of reactive oxygen, nitrogen, and chlorine species, but they are relatively resistant to oxidation mediated by the potent oxidant peroxynitrite and hypochlorous acid rather than peroxyl radicals $[69,70]$. Lai et al. reported that isoflavones can scavenge peroxynitrite, a potent oxidant formed in vivo from the reaction of nitric oxide with superoxide, to prevent the nitration of tyrosine, while genistein and daidzein dose-dependently inhibit peroxynitrite-mediated low-density lipoprotein (LDL) oxidation [71]. Genistein is able to normalize the increased superoxide anion production and nitrotyrosine formation in streptozotocin-induced type 1 diabetic mice [72]. Isoflavones-enriched Trifolium extracts reduce the peroxynitrite-mediated modifications of proteins and diminish peroxidation of lipids in blood platelets [73]. Moreover, oral administration of isoflavones and extracts of soy products decrease serum nitrite, nitrate, and nitrotyrosine levels in LPS-challenged rats [74]. These results suggest that isoflavones scavenge increased free radicals produced by activated macrophages during inflammation, thereby preventing $\mathrm{NO}$ reactions with free radicals and the subsequent production of peroxynitrite that can directly oxidize LDL and result in irreversible damage to the cell membrane.

Lately, soy isoflavone has been shown to decrease the concentrations of ROS and malondialdehyde, as well as increase the mRNA expressions and activities of superoxide dismutase and glutathione 
peroxidase in porcine mammary gland cells and human umbilical vein endothelial cells challenged by hydrogen peroxide [75,76]. These interesting findings, along with a previous report [45], indicate that isoflavones are modulators of enzymatic antioxidants (besides ROS scavengers), and that nuclear factor-erythroid 2 (Nrf2) - a key transcription factor that leads to gene transcription of various antioxidant and phase II detoxifying enzymes—is associated with this modulation [77,78].

\subsection{Pro-Inflammatory Cytokines and Chemokines Production}

Inhibiting the production of pro-inflammatory cytokines and chemokines such as IL-1 $\beta$, IL-6, IL-12, and TNF- $\alpha$ is a major mechanism by which isoflavones exert anti-inflammatory functions (Figure 2). Macrophages are the major cells releasing pro-inflammatory cytokines. Isoflavone pretreatment has been shown to regulate gene transcription of cytokines and inflammatory markers, and to inhibit the overproduction of NO and PGE 2 induced by LPS plus IFN- $\gamma$ in RAW 264.7 macrophages by transcriptomic profiling [79]. A recent study demonstrated that genistein effectively suppresses the LPS-stimulated overproduction of IL-6 and TNF- $\alpha$ in RAW 264.7 macrophages [80]. Irisflorentin, a naturally occurring isoflavone, also significantly inhibits TNF- $\alpha$, IL-1 $\beta$, and IL- 6 at both transcriptional and translational levels in LPS-induced RAW 264.7 macrophages [81]. Moreover, isoflavones fraction suppresses TNF- $\alpha$-induced IL- 8 secretion, and inhibits the IL- 8 promoter activity in human intestinal epithelial Caco-2 cells, thereby suggesting isoflavones are promising food components for preventing intestinal inflammation [82]. Daidzein is found to inhibit IL-6 and IL-8 production in Toll-like receptor (TLR)2, and TLR4-stimulated monocytes in a dose-dependent manner [83]. In addition to in vitro evidence, isoflavones suppress pro-inflammatory cytokines and chemokines during inflammatory reaction in diverse animal models and humans $[21,45,49,84]$. In a murine model of human inflammatory demyelinating disease, genistein impressively down-modulates IFN- $\gamma$ and IL-12 cytokine in the brain, thereby suggesting genistein might be a potential therapy for multiple sclerosis [85]. Genistein supplementation significantly decreases the mRNA levels of TNF- $\alpha$ and IL-1 $\beta$, and alleviates hepatic inflammation and fibrosis in nonalcoholic fatty liver disease $d b / d b$ mice [86]. In a randomized phase II trial, consumption of soy isoflavone enriched bread was shown to reduce pro-inflammatory cytokines with limiting inflammation and results in the suppression of myeloid-derived suppressor cells in men with prostate cancer [84].

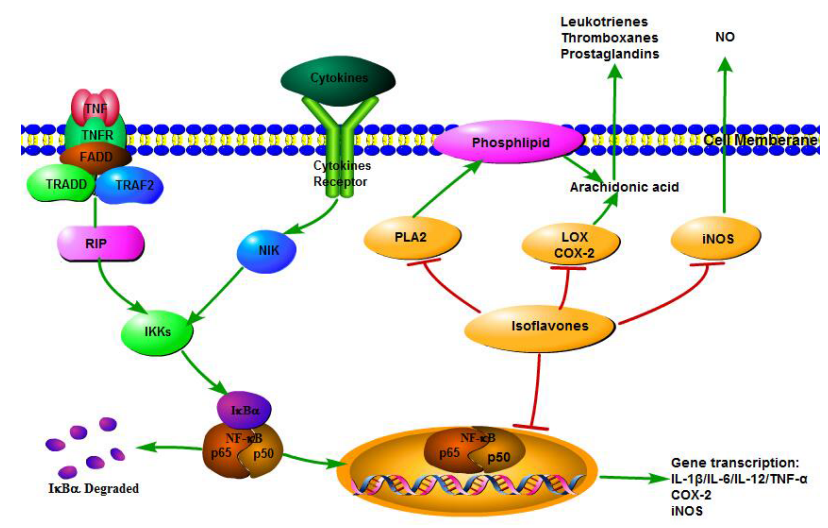

Figure 2. Anti-inflammatory mechanisms of isoflavones. Upon stimulation, cytoplasmic NF- $\mathrm{B}$ is activated by IкB kinase (IKK). Then, free NF- $\kappa B$ translocates into the nucleus and activates the transcription of target genes including pro-inflammatory cytokines and chemokines, inducible nitric oxide synthases (iNOS), and cyclooxygenase 2 (COX-2). Isoflavones decrease the production of these pro-inflammatory contributors by inhibiting the NF- $\mathrm{KB}$ transcriptional system. Also, isoflavones modulate arachidonic acid (AA) metabolism and NO production by inhibiting the protein levels and activities of pro-inflammatory enzymes (phospholipase A2 (PLA2), lipoxygenase (LOX), COX-2, and iNOS). The metabolites of AA-including prostaglandins (PG), leukotrienes and thromboxances, and $\mathrm{NO}-$ are crucial mediators of inflammation. 


\subsection{Pro-Inflammatory Enzyme Activities}

Arachidonic acid (AA) related enzymes such as cyclooxygenase (COX), lipoxygenase (LOX), and phospholipase A2 (PLA2), plus nitric oxide synthases (NOSs) are typical pro-inflammatory enzymes which catalyze the production of vital inflammatory mediators including prostaglandins (PG), leukotrienes, AA, and NO [87-90].

When a general inflammatory response is induced, cytosolic PLA2 action triggers the release of AA from membrane phospholipids [91]. AA is then metabolized to PG and thromboxances by COX, or leukotrienes by LOX [21]. Isoflavones can modulate AA metabolism by inhibiting the protein levels and activities of AA related enzymes, providing a possible mechanisms to explain the anti-inflammatory functions of isoflavones (Figure 2).

Genistein inhibits secretory PLA2 activity of both inflammatory exudates and snake venoms in a concentration dependent manner [92]. An isoflavone isolated from Harpalyce brasiliana Benth, harpalycin 2, has been found to inhibit the enzymatic, edematogenic, and myotoxic activities of secretory PLA2 from various snake venoms, and harpalycin 2 significantly suppresses PLA2-induced edema at the initial step [93]. Furthermore, docking calculations indicated that the residues His 48 and Asp49 powerfully interact with harpalycin 2 through hydrogen bonds in the active site of PLA2 [93].

There are two isoforms of COX in mammals. COX-1 is a constitutive enzyme widely distributed in most cell types to catalyze PG synthesis in normal physiological conditions, whereas COX-2 is an inducible enzyme specifically presented in inflammatory cells to respond to bacterial LPS and/or pro-inflammatory cytokines [21,94]. Genistein and daidzein alleviate aortic endothelium-dependent contraction to acetylcholine in spontaneously hypertensive rats by inhibiting COX activity and reducing the endothelial prostaglandin $\mathrm{H} 2$ release [95]. Isoflavones from soybean and tempeh ameliorate scopolamine-induced amnesia in rats by disrupting COX-2 action and preventing neuroinflammation [96]. Other than in vivo inhibitory effects of isoflavones on COX-2, in vitro experiments have also demonstrated the suppressive effect of isoflavones on COX-2 expression and activity. Genistein and daidzein inhibit phorbol 12-myristate 13-acetate (PMA) induced COX-2 transcription and protein expression in the breast cell line MCF-7 culture system [97]. Nonetheless, isoflavones suppression of the COX-2 promoter transactivation may be dependent on AP-1/CREB binding [97]. In the human gastric cancer cell line BGC-823, genistein treatment markedly decreases COX-2 protein levels in a dose-dependent manner, inhibiting cell proliferation and inducing apoptosis [98].

LOX metabolizes AA to leukotrienes and hydroxyl acids, and is involved in the onset and the development of a diverse number of human diseases [21]. The inhibitory effect of isoflavones has been identified. Genistein and daidzein are noncompetitive inhibitors of the activity of 5-LOX from human polymorph nuclear leukocytes in a concentration dependent manner [99]. Enzymatic evaluation indicates that isoflavone texasin is an effective 5-LOX inhibitor [100]. An in vitro experiment has shown that isoflavones suppress the activities of human platelet 12-LOX, reticulocyte 15-LOX-1, and epithelial 15-LOX-2, and a catechol group in ring A of isoflavones might be critical for the inhibitory effect according to a docking study [101]. Mechanically, isoflavones are able to convert the active form (ferric state) of LOX to the resting form (ferrous state) or prevent the activation of the resting state, thereby regulating LOX activity [2].

The NOS family includes endothelial NOS (eNOS), neuronal NOS (nNOS), and inducible NOS (iNOS), producing NO, a ubiquitous cellular mediator of physiological and pathological processes, from L-arginine. Other than constitutively producing low physiological levels of NO by eNOS and nNOS, iNOS is induced by bacterial LPS and/or pro-inflammatory cytokines to overproduce NO in macrophages and other cells [102,103]. Isoflavones have been shown to inhibit NO production by iNOS from certain cells without affecting eNOS and nNOS, making isoflavones the desirable anti-inflammatory agents. Primary isoflavones genistein, daidzein, and glycitein dose-dependently suppress NO production, and inhibit both the activity and expression of iNOS in LPS-stimulated murine macrophages [104]. In primary cultured microglia and the BV2 
microglial cell line, isoflavones repress LPS-induced iNOS expression at both the transcriptional and post-transcriptional level $[105,106]$. Genistein administration is also found to prevent the increases of iNOS activity in diabetic wound tissues in a dose-dependent manner [72]. On the contrary, a previous study showed that genistein and daidzein activate iNOS and enhance NO production through the estrogen receptor (ER) pathway in RAW 264.7 macrophages [107]. In light of these experimental data, isoflavones may act to maintain the production of $\mathrm{NO}$ in normal physiological conditions, but prevent the overproduction of NO through inhibiting the expression and activity of iNOS in a pathological state.

\subsection{NF-кB Transcriptional System}

A number of cellular signaling cascades are involved in the anti-inflammatory activity of isoflavones. The isoflavones activation of adenosine monophosphate-activated protein kinase (AMPK), protein kinase $\mathrm{C}(\mathrm{PKC})$, and mitogen-activated protein kinase (MAPK) regulate the DNA-binding capacity of transcription factors like NF- $\mathrm{B}$ and activator protein-1 (AP-1) and lead to the subsequent increases of target gene transcription $[78,80,105,106,108]$. In addition, $N F-\kappa B$ is the major effector in inflammatory and immune response [109]. Thus, the NF- $\kappa B$ transcriptional system is considered to be the control point in the anti-inflammatory function of isoflavones (Figure 2).

Upon stimulation, the inhibitor of NF- $\mathrm{B}, \mathrm{I} \kappa \mathrm{B}$, is phosphorylated and then degraded to set NF- $\kappa B$ free. Cytoplasmic NF- $\mathrm{B}$ subsequently translocates into the nucleus and activates the transcription of target genes including pro-inflammatory cytokines and chemokines, and adhesion molecules, iNOS, and COX-2 [110]. Furthermore, the Ser536 on the p65 subunit of NF-kB can be phosphorylated and activated by IкB kinase (IKK) after LPS stimulation [111]. This IкB independent pathway is also a mechanism by which NF- $\kappa B$ regulates gene transcription and pro-inflammatory cytokines production in addition to the canonical regulation of NF- $\kappa$ B induction [112]. The isoflavone genistein, but not daidzein, represses TNF- $\alpha$-induced NF- $\mathrm{B}$ activation in human peripheral blood lymphocytes, and an isoflavone mixture also inhibits TNF- $\alpha$-induced NF- $\kappa$ B activation and oxidative DNA damage in healthy men [113]. However, another study demonstrates that daidzein attenuates ischemia/reperfusion-induced myocardial damage via inhibiting NF- $\mathrm{kB}$ activation in rats [114]. A previous study indicated that genistein attenuates hemolysate-induced NF- $\mathrm{KB}$ p65 translocation in rat brain microvascular endothelial cells, which in turn suppresses the expression levels of pro-inflammatory and adhesion molecules [115]. Recently, genistein supplementation was shown to accelerate diabetic wound closure rate and decrease pro-inflammatory cytokines, iNOS, and COX-2 by inhibition of I $\kappa B$ phosphorylation, and subsequent NF- $\kappa B$ activation [116], thereby suggesting isoflavones regulate NF- $k$ B activation through both I $\mathrm{B}$ dependent and independent pathways.

\section{Potential Health Risks of Isoflavones Intake}

Numerous studies have provided a wealth of information on the anti-inflammatory effects and the underlying mechanisms of isoflavones, however, some studies have raised concerns about isoflavones induced negative effects.

As mentioned above, isoflavones are usually classified as phytoestrogens which have both estrogenic and anti-estrogenic effects. It has been suggested that isoflavones can either activate ER $\alpha$ to promote cell proliferation or bind to ER $\beta$ to promote apoptosis [117]. So even if isoflavones are widely known as prospective compounds for preventing carcinogenesis [27,118], especially breast cancer [27,119-122], they have been shown to promote tumor development and elevate cancer risk in some research studies [123]. Previous studies discovered that genistein increases the percentage of proliferative cells in tumors, enhances tumor multiplicity, and elevates the weight of estrogen-dependent mammary adenocarcinomas in rats [124,125]. Moreover, neonatal exposure to genistein increases uterine fibroid incidence and multiplicity in Eker rats via impairing myometrial DNA repair capacity [126,127]. Administration of genistein or daidzein also induces apoptosis in human prostate hyperplasia cells, indicating that individual isoflavones may be cytotoxic for 
non-cancerous cells [128]. There are two hypotheses put forward to explain the seemingly contradictory health effects. One is a balance between two opposing receptors (ER $\alpha$ and ER $\beta$ ) in cells. The eventual outcome might be an interactive effect among many complex mechanisms depending on the factors which change the ER condition in the cell, including cellular context, balance between ER subtypes, or co-activators and co-repressors, and so on. Another hypothesis is that epigenetics, such as DNA methylation, histone modification, and miRNA expression patterns, could adjust the role of the effect of isoflavones on cancer [129]. Therefore, the relationship between isoflavones and cancer does not always appear to be positive, and the potential carcinogenic risk should be considered.

Similarly, isoflavones offer immunologic benefits to various animals, but a few studies have raised the possibility of immunosuppression by isoflavones. Genistein injection leads to dose-dependent decreases in thymic weight up to $80 \%$, reduces thymocyte numbers, increases thymocyte apoptosis, and suppresses humoral and cellular immune response through either ER- or non-ER-mediated pathways in ovariectomized juvenile mice $[130,131]$. The most recent research has demonstrated that dietary soy isoflavones during the prenatal period significantly cause lymphocytic depletion in white pulp of the spleen and decrease thymic relative weights in rat offspring [132].

Long-term consumption is one of the key factors of consideration concerning the safety of isoflavones. Epidemiological data from Hawaiian populations indicated that there is an association between long-term soy consumption and Kawasaki disease (KD), and soy isoflavones are involved in KD pathogenesis [133]. In addition, a recent study shows that isoflavone exposure via consumption of soy-based infant formula negatively affects the long-term development of infants [134]. Long-term exposure to genistein promotes the growth of breast cancer cells and results in soy protein isolate-induced non-regressing tumors with more aggressive and advanced growth phenotypes [135].

Another key factor which may elevate the healthy risk of isoflavones is high dosage. A recent meta-analysis shows that high intake of soy isoflavones increases the risk of cancer recurrence in epidermal growth factor receptor-2 (HER-2)-positive breast cancer in Korean women [136]. Supplementation with a high dose $(150 \mathrm{mg} / \mathrm{BW})$ of genistein during a 21-day gestation period induces adverse effects on the reproductive organs of first generation (F1) murine weanling-stage offspring [137]. Another dose range-finding study was conducted as a prelude to a multi-generation bioassay to assess potential toxicities associated with genistein consumption [138]. It has been demonstrated that exposure to over $25 \mathrm{mg} / \mathrm{kg}$ feed of genistein significantly inhibits breast tissue hyperplasia and hypertrophy, decreases offspring birth weight, reduces male offspring prostate weight, delays testicular developmental, and induces sperm retardation and deformation [138]. Studies by our group indicated that the biological activity of daidzein in pigs depends on dosage [139]. Dietary supplementation with a higher dose of daidzein $(400 \mathrm{mg} / \mathrm{kg}$ feed) decreases body weight gain and increases the splenic damage index in weaned pigs [139]. In vitro studies also show contrasting effects, that isoflavones show a strong cardioprotective activity at low concentrations and cardiotoxic activity at high concentrations [140]. Furthermore, high concentrations (such as $200 \mu \mathrm{M}$ ) of genistein exert pro-oxidant potential in primary porcine muscle cells by enhancing ROS production in a 5-LOX-dependent manner [141].

In summary, the potential risks of isoflavones have been highlighted in some investigations. However, the current literature is quite incomplete and sometimes contradictory. The negative effects of isoflavones may rely on diverse factors such as age at the time of exposure and the hormonal environment.

\section{Conclusions}

As shown by this summary of abundant evidence, isoflavones exhibit impressive anti-inflammatory properties in various animal models, and even in humans, through increased antioxidative activities, NF- $\kappa B$ regulation, and reduced pro-inflammatory enzymes activities and cytokine levels, thereby encouraging the application of isoflavones in a range of inflammatory diseases. Noticeably, the potential carcinogenic and immunosuppressive effects of isoflavone raise concerns 
about the risks of isoflavone consumption. However, extensive evaluations are still warranted to explore the exact mechanisms and answer the safety question. At the present time, this concise work may renew certain knowledge of isoflavones in inflammatory process, and may draw the attention of the public to vegetarian diets and natural medicine.

Acknowledgments: This work was supported by National Science \& Technology Pillar Program (2014BAD13B01), and Key Project in Sichuan Science \& Technology Pillar Program (2013NZ0056).

Author Contributions: Jie Yu collected literature and drafted the manuscript; Xiaojuan Bi collected literature; Bing Yu revised the manuscript; Daiwen Chen designed the review and revised the paper.

Conflicts of Interest: The authors declare no conflict of interest.

\section{References}

1. Barton, G.M. A calculated response: Control of inflammation by the innate immune system. J. Clin. Investig. 2008, 118, 413-420. [CrossRef] [PubMed]

2. Garcia-Lafuente, A.; Guillamon, E.; Villares, A.; Rostagno, M.A.; Martinez, J.A. Flavonoids as anti-inflammatory agents: Implications in cancer and cardiovascular disease. Inflamm. Res. 2009, 58, 537-552. [CrossRef] [PubMed]

3. Libby, P. Inflammation in atherosclerosis. Nature 2002, 420, 868-874. [CrossRef] [PubMed]

4. Samad, F.; Ruf, W. Inflammation, obesity, and thrombosis. Blood 2013, 122, 3415-3422. [CrossRef] [PubMed]

5. Khandpur, R.; Carmona-Rivera, C.; Vivekanandan-Giri, A.; Gizinski, A.; Yalavarthi, S.; Knight, J.S.; Friday, S.; Li, S.; Patel, R.M.; Subramanian, V.; et al. Nets are a source of citrullinated autoantigens and stimulate inflammatory responses in rheumatoid arthritis. Sci. Transl. Med. 2013, 5, 178ra140. [CrossRef] [PubMed]

6. Shay, J.; Elbaz, H.A.; Lee, I.; Zielske, S.P.; Malek, M.H.; Huttemann, M. Molecular mechanisms and therapeutic effects of (-)-epicatechin and other polyphenols in cancer, inflammation, diabetes, and neurodegeneration. Oxidative Med. Cell. Longev. 2015, 2015, 181260. [CrossRef] [PubMed]

7. Elinav, E.; Nowarski, R.; Thaiss, C.A.; Hu, B.; Jin, C.; Flavell, R.A. Inflammation-induced cancer: Crosstalk between tumours, immune cells and microorganisms. Nat. Rev. Cancer 2013, 13, 759-771. [CrossRef] [PubMed]

8. Coxib and traditional NSAID Trialists' (CNT) Collaboration; Bhala, N.; Emberson, J.; Merhi, A.; Abramson, S.; Arber, N.; Baron, J.A.; Bombardier, C.; Cannon, C.; Farkouh, M.E.; et al. Vascular and upper gastrointestinal effects of non-steroidal anti-inflammatory drugs: Meta-analyses of individual participant data from randomised trials. Lancet 2013, 382, 769-779.

9. Trichopoulou, A.; Bamia, C.; Trichopoulos, D. Anatomy of health effects of mediterranean diet: Greek epic prospective cohort study. BMJ 2009, 338, b2337. [CrossRef] [PubMed]

10. Ros, E.; Hu, F.B. Consumption of plant seeds and cardiovascular health: Epidemiological and clinical trial evidence. Circulation 2013, 128, 553-565. [CrossRef] [PubMed]

11. Woo, K.S.; Kwok, T.C.; Celermajer, D.S. Vegan diet, subnormal vitamin b-12 status and cardiovascular health. Nutrients 2014, 6, 3259-3273. [CrossRef] [PubMed]

12. Li, S.; Zhang, B. Traditional Chinese medicine network pharmacology: Theory, methodology and application. Chin. J. Nat. Med. 2013, 11, 110-120. [CrossRef] [PubMed]

13. Yin, T.; Yang, G.; Ma, Y.; Xu, B.; Hu, M.; You, M.; Gao, S. Developing an activity and absorption-based quality control platform for chinese traditional medicine: Application to zeng-sheng-ping (antitumor b). J. Ethnopharmacol. 2015, 172, 195-201. [CrossRef] [PubMed]

14. Bo, Y.; Yuan, L.P.; Zhang, J.J.; Meng, D.D.; Jing, H.; Dai, H.J. Total flavonoids of bidens bipinnata 1. A traditional Chinese medicine inhibits the production of inflammatory cytokines of vessel endothelial cells stimulated by sera from henoch-schonlein purpura patients. J. Pharm. Pharmacol. 2012, 64, 882-887. [CrossRef] [PubMed]

15. Dower, J.I.; Geleijnse, J.M.; Gijsbers, L.; Schalkwijk, C.; Kromhout, D.; Hollman, P.C. Supplementation of the pure flavonoids epicatechin and quercetin affects some biomarkers of endothelial dysfunction and inflammation in (pre)hypertensive adults: A randomized double-blind, placebo-controlled, crossover trial. J. Nutr. 2015, 145, 1459-1463. [CrossRef] [PubMed] 
16. Dower, J.I.; Geleijnse, J.M.; Gijsbers, L.; Zock, P.L.; Kromhout, D.; Hollman, P.C. Effects of the pure flavonoids epicatechin and quercetin on vascular function and cardiometabolic health: A randomized, double-blind, placebo-controlled, crossover trial. Am. J. Clin. Nutr. 2015, 101, 914-921. [CrossRef] [PubMed]

17. Esposito, D.; Chen, A.; Grace, M.H.; Komarnytsky, S.; Lila, M.A. Inhibitory effects of wild blueberry anthocyanins and other flavonoids on biomarkers of acute and chronic inflammation in vitro. J. Agric. Food Chem. 2014, 62, 7022-7028. [CrossRef] [PubMed]

18. Terashima, M.; Kakuno, Y.; Kitano, N.; Matsuoka, C.; Murase, M.; Togo, N.; Watanabe, R.; Matsumura, S. Antioxidant activity of flavonoids evaluated with myoglobin method. Plant Cell Rep. 2012, 31, 291-298. [CrossRef] [PubMed]

19. Crozier, A.; Jaganath, I.B.; Clifford, M.N. Dietary phenolics: Chemistry, bioavailability and effects on health. Nat. Prod. Rep. 2009, 26, 1001-1043. [CrossRef] [PubMed]

20. Sakai, T.; Kogiso, M. Soy isoflavones and immunity. J. Med. Investig. 2008, 55, 167-173. [CrossRef]

21. Marzocchella, L.; Fantini, M.; Benvenuto, M.; Masuelli, L.; Tresoldi, I.; Modesti, A.; Bei, R. Dietary flavonoids: Molecular mechanisms of action as anti-inflammatory agents. Recent Pat. Inflamm. Allergy Drug Discov. 2011, 5, 200-220. [CrossRef] [PubMed]

22. Cassidy, A.; Hanley, B.; Lamuela-Raventos, R.M. Isoflavones, lignans and stilbenes-Origins, metabolism and potential importance to human health. J. Sci. Food Agric. 2000, 80, 1044-1062. [CrossRef]

23. Perez-Jimenez, J.; Neveu, V.; Vos, F.; Scalbert, A. Systematic analysis of the content of 502 polyphenols in 452 foods and beverages: An application of the phenol-explorer database. J. Agric. Food Chem. 2010, 58, 4959-4969. [CrossRef] [PubMed]

24. Setchell, K.D.; Nardi, E.; Battezzati, P.-M.; Asciutti, S.; Castellani, D.; Perriello, G.; Clerici, C. Novel soy germ pasta enriched in isoflavones ameliorates gastroparesis in type 2 diabetes a pilot study. Diabetes Care 2013, 36, 3495-3497. [CrossRef] [PubMed]

25. Barros, R.P.; Gustafsson, J.Å. Estrogen receptors and the metabolic network. Cell Metab. 2011, 14, $289-299$. [CrossRef] [PubMed]

26. Vitale, D.C.; Piazza, C.; Melilli, B.; Drago, F.; Salomone, S. Isoflavones: Estrogenic activity, biological effect and bioavailability. Eur. J. Drug Metab. Pharmacokinet. 2013, 38, 15-25. [CrossRef] [PubMed]

27. Conklin, C.M.; Bechberger, J.F.; MacFabe, D.; Guthrie, N.; Kurowska, E.M.; Naus, C.C. Genistein and quercetin increase connexin43 and suppress growth of breast cancer cells. Carcinogenesis 2007, 28, 93-100. [CrossRef] [PubMed]

28. Dhayakaran, R.P.A.; Neethirajan, S.; Xue, J.; Shi, J. Characterization of antimicrobial efficacy of soy isoflavones against pathogenic biofilms. LWT Food Sci. Technol. 2015, 63, 859-865. [CrossRef]

29. Rodríguez-Roque, M.J.; Rojas-Graü, M.A.; Elez-Martínez, P.; Martín-Belloso, O. Soymilk phenolic compounds, isoflavones and antioxidant activity as affected by in vitro gastrointestinal digestion. Food Chem. 2013, 136, 206-212. [CrossRef] [PubMed]

30. Chacko, B.K.; Chandler, R.T.; D'Alessandro, T.L.; Mundhekar, A.; Khoo, N.K.; Botting, N.; Barnes, S.; Patel, R.P. Anti-inflammatory effects of isoflavones are dependent on flow and human endothelial cell ppargamma. J. Nutr. 2007, 137, 351-356. [PubMed]

31. Kuiper, G.G.; Lemmen, J.G.; Carlsson, B.; Corton, J.C.; Safe, S.H.; van der Saag, P.T.; van der Burg, B.; Gustafsson, J.-A.K. Interaction of estrogenic chemicals and phytoestrogens with estrogen receptor $\beta$. Endocrinology 1998, 139, 4252-4263. [PubMed]

32. Phetnoo, N.; Werawatganon, D.; Siriviriyakul, P. Genistein could have a therapeutic potential for gastrointestinal diseases. Thai J. Gastroenterol. 2013 2013, 14, 120-125.

33. Marugame, T.; Katanoda, K. International comparisons of cumulative risk of breast and prostate cancer, from cancer incidence in five continents vol. Viii. Jpn. J. Clin. Oncol. 2006, 36, 399-400. [CrossRef] [PubMed]

34. Medjakovic, S.; Mueller, M.; Jungbauer, A. Potential health-modulating effects of isoflavones and metabolites via activation of ppar and ahr. Nutrients 2010, 2, 241-279. [CrossRef] [PubMed]

35. Wu, A.H.; Ziegler, R.G.; Nomura, A.; West, D.W.; Kolonel, L.N.; Horn-Ross, P.L.; Hoover, R.N.; Pike, M.C. Soy intake and risk of breast cancer in asians and asian americans. Am. J. Clin. Nutr. 1998, 68, 1437S-1443S. [PubMed]

36. Nielsen, I.L.; Williamson, G. Review of the factors affecting bioavailability of soy isoflavones in humans. Nutr. Cancer 2007, 57, 1-10. [CrossRef] [PubMed] 
37. Vergne, S.; Titier, K.; Bernard, V.; Asselineau, J.; Durand, M.; Lamothe, V.; Potier, M.; Perez, P.; Demotes-Mainard, J.; Chantre, P.; et al. Bioavailability and urinary excretion of isoflavones in humans: Effects of soy-based supplements formulation and equol production. J. Pharm. Biomed. Anal. 2007, 43, 1488-1494. [CrossRef] [PubMed]

38. Day, A.J.; DuPont, M.S.; Ridley, S.; Rhodes, M.; Rhodes, M.J.; Morgan, M.R.; Williamson, G. Deglycosylation of flavonoid and isoflavonoid glycosides by human small intestine and liver $\beta$-glucosidase activity. FEBS Lett. 1998, 436, 71-75. [CrossRef]

39. Setchell, K.D.; Brown, N.M.; Desai, P.; Zimmer-Nechemias, L.; Wolfe, B.E.; Brashear, W.T.; Kirschner, A.S.; Cassidy, A.; Heubi, J.E. Bioavailability of pure isoflavones in healthy humans and analysis of commercial soy isoflavone supplements. J. Nutr. 2001, 131, 1362S-1375S. [PubMed]

40. Barnes, S. The biochemistry, chemistry and physiology of the isoflavones in soybeans and their food products. Lymphat. Res. Biol. 2010, 8, 89-98. [CrossRef] [PubMed]

41. Manach, C.; Williamson, G.; Morand, C.; Scalbert, A.; Rémésy, C. Bioavailability and bioefficacy of polyphenols in humans. I. Review of 97 bioavailability studies. Am. J. Clin. Nutr. 2005, 81, 230S-242S. [PubMed]

42. Barnes, S. Evolution of the health benefits of soy isoflavones. Proc. Soc. Exp. Biol. Med. 1998, 217, $386-392$. [CrossRef] [PubMed]

43. Messina, M. Soy foods, isoflavones, and the health of postmenopausal women. Am. J. Clin. Nutr. 2014, 100, 423S-430S. [CrossRef] [PubMed]

44. Verdrengh, M.; Jonsson, I.M.; Holmdahl, R.; Tarkowski, A. Genistein as an anti-inflammatory agent. Inflamm. Res. Off. J. Eur. Histamine Res. Soc. 2003, 52, 341-346. [CrossRef] [PubMed]

45. Paradkar, P.N.; Blum, P.S.; Berhow, M.A.; Baumann, H.; Kuo, S.M. Dietary isoflavones suppress endotoxin-induced inflammatory reaction in liver and intestine. Cancer Lett. 2004, 215, 21-28. [CrossRef] [PubMed]

46. Kao, T.H.; Wu, W.M.; Hung, C.F.; Wu, W.B.; Chen, B.H. Anti-inflammatory effects of isoflavone powder produced from soybean cake. J. Agric. Food Chem. 2007, 55, 11068-11079. [CrossRef] [PubMed]

47. Carrara, V.S.; Melo, J.O.; Filho, B.; Bersani-Amado, C.A.; Nakamura, C.V.; Mandarino, J.; Cortez, L.; Cortez, D. Anti-inflammatory activity of the soybean methanolic fraction containing isoflavones. Planta Medica 2008, 74, 1179. [CrossRef]

48. Lim, D.W.; Lee, C.; Kim, I.H.; Kim, Y.T. Anti-inflammatory effects of total isoflavones from pueraria lobata on cerebral ischemia in rats. Molecules 2013, 18, 10404-10412. [CrossRef] [PubMed]

49. Ganai, A.A.; Khan, A.A.; Malik, Z.A.; Farooqi, H. Genistein modulates the expression of nf-kappab and mapk (p-38 and erk1/2), thereby attenuating D-galactosamine induced fulminant hepatic failure in wistar rats. Toxicol. Appl. Pharmacol. 2015, 283, 139-146. [CrossRef] [PubMed]

50. Duan, W.; Kuo, I.C.; Selvarajan, S.; Chua, K.Y.; Bay, B.H.; Wong, W.S. Antiinflammatory effects of genistein, a tyrosine kinase inhibitor, on a guinea pig model of asthma. Am. J. Respir. Crit. Care Med. 2003, 167, 185-192. [CrossRef] [PubMed]

51. Hooshmand, S.; Soung do, Y.; Lucas, E.A.; Madihally, S.V.; Levenson, C.W.; Arjmandi, B.H. Genistein reduces the production of proinflammatory molecules in human chondrocytes. J. Nutr. Biochem. 2007, 18, 609-614. [CrossRef] [PubMed]

52. Li, H.Y.; Pan, L.; Ke, Y.S.; Batnasan, E.; Jin, X.Q.; Liu, Z.Y.; Ba, X.Q. Daidzein suppresses pro-inflammatory chemokine cxcl2 transcription in tnf-alpha-stimulated murine lung epithelial cells via depressing parp-1 activity. Acta Pharmacol. Sin. 2014, 35, 496-503. [CrossRef] [PubMed]

53. Tanaka, K.; Ohgo, Y.; Katayanagi, Y.; Yasui, K.; Hiramoto, S.; Ikemoto, H.; Nakata, Y.; Miyoshi, N.; Isemura, M.; Ohashi, N.; et al. Anti-inflammatory effects of green soybean extract irradiated with visible light. Sci. Rep. 2014, 4, 4732. [CrossRef] [PubMed]

54. Han, S.; Wu, H.; Li, W.; Gao, P. Protective effects of genistein in homocysteine-induced endothelial cell inflammatory injury. Mol. Cell. Biochem. 2015, 403, 43-49. [CrossRef] [PubMed]

55. Azadbakht, L.; Kimiagar, M.; Mehrabi, Y.; Esmaillzadeh, A.; Hu, F.B.; Willett, W.C. Soy consumption, markers of inflammation, and endothelial function a cross-over study in postmenopausal women with the metabolic syndrome. Diabetes Care 2007, 30, 967-973. [CrossRef] [PubMed] 
56. Nasca, M.M.; Zhou, J.-R.; Welty, F.K. Effect of soy nuts on adhesion molecules and markers of inflammation in hypertensive and normotensive postmenopausal women. Am. J. Cardiol. 2008, 102, 84-86. [CrossRef] [PubMed]

57. Fanti, P.; Asmis, R.; Stephenson, T.J.; Sawaya, B.P.; Franke, A.A. Positive effect of dietary soy in esrd patients with systemic inflammation-Correlation between blood levels of the soy isoflavones and the acute-phase reactants. Nephrol. Dial. Transplant. 2006, 21, 2239-2246. [CrossRef] [PubMed]

58. Ferguson, J.F.; Ryan, M.F.; Gibney, E.R.; Brennan, L.; Roche, H.M.; Reilly, M.P. Dietary isoflavone intake is associated with evoked responses to inflammatory cardiometabolic stimuli and improved glucose homeostasis in healthy volunteers. Nutr. Metab. Cardiovasc. Dis. 2014, 24, 996-1003. [CrossRef] [PubMed]

59. Wu, S.H.; Shu, X.O.; Chow, W.-H.; Xiang, Y.-B.; Zhang, X.; Li, H.-L.; Cai, Q.; Ji, B.-T.; Cai, H.; Rothman, N. Soy food intake and circulating levels of inflammatory markers in Chinese women. J. Acad. Nutr. Diet. 2012, 112, 996-1004. [CrossRef] [PubMed]

60. Mangano, K.M.; Hutchins-Wiese, H.L.; Kenny, A.M.; Walsh, S.J.; Abourizk, R.H.; Bruno, R.S.; Lipcius, R.; Fall, P.; Kleppinger, A.; Kenyon-Pesce, L. Soy proteins and isoflavones reduce interleukin-6 but not serum lipids in older women: A randomized controlled trial. Nutr. Res. 2013, 33, 1026-1033. [CrossRef] [PubMed]

61. Acharjee, S.; Zhou, J.-R.; Elajami, T.K.; Welty, F.K. Effect of soy nuts and equol status on blood pressure, lipids and inflammation in postmenopausal women stratified by metabolic syndrome status. Metabolism 2015, 64, 236-243. [CrossRef] [PubMed]

62. Lee, D.J.; Kang, S.W. Reactive oxygen species and tumor metastasis. Mol. Cells 2013, 35, 93-98. [CrossRef] [PubMed]

63. Brown, G.C.; Neher, J.J. Microglial phagocytosis of live neurons. Nat. Rev. Neurosci. 2014, 15, $209-216$. [CrossRef] [PubMed]

64. Halliwell, B.; Gutteridge, J.M. Free Radicals in Biology and Medicine; Oxford University Press: New York, NY, USA, 2015.

65. Niki, E. Role of vitamin E as a lipid-soluble peroxyl radical scavenger: In vitro and in vivo evidence. Free Radic. Biol. Med. 2014, 66, 3-12. [CrossRef] [PubMed]

66. Lee, I.-T.; Yang, C.-M. Role of nadph oxidase/ros in pro-inflammatory mediators-induced airway and pulmonary diseases. Biochem. Pharmacol. 2012, 84, 581-590. [CrossRef] [PubMed]

67. Lengyel, J.; Rimarčík, J.; Vagánek, A.; Klein, E. On the radical scavenging activity of isoflavones: Thermodynamics of O-H bond cleavage. Phys. Chem. Chem. Phys. 2013, 15, 10895-10903. [CrossRef] [PubMed]

68. D'Alessandro, T.; Prasain, J.; Benton, M.; Botting, N.; Moore, R.; Darley-Usmar, V.; Patel, R.; Barnes, S. Polyphenols, inflammatory response, and cancer prevention: Chlorination of isoflavones by human neutrophils. J. Nutr. 2003, 133, 3773S-3777S. [PubMed]

69. Patel, R.P.; Boersma, B.J.; Crawford, J.H.; Hogg, N.; Kirk, M.; Kalyanaraman, B.; Parks, D.A.; Barnes, S.; Darley-Usmar, V. Antioxidant mechanisms of isoflavones in lipid systems: Paradoxical effects of peroxyl radical scavenging. Free Radic. Biol. Med. 2001, 31, 1570-1581. [CrossRef]

70. Boersma, B.J.; Patel, R.P.; Kirk, M.; Jackson, P.L.; Muccio, D.; Darley-Usmar, V.M.; Barnes, S. Chlorination and nitration of soy isoflavones. Arch. Biochem. Biophys. 1999, 368, 265-275. [CrossRef] [PubMed]

71. Lai, H.H.; Yen, G.C. Inhibitory effect of isoflavones on peroxynitrite-mediated low-density lipoprotein oxidation. Biosci. Biotechnol. Biochem. 2002, 66, 22-28. [CrossRef] [PubMed]

72. Tie, L.; An, Y.; Han, J.; Xiao, Y.; Xiaokaiti, Y.; Fan, S.; Liu, S.; Chen, A.F.; Li, X. Genistein accelerates refractory wound healing by suppressing superoxide and foxo1/inos pathway in type 1 diabetes. J. Nutr. Biochem. 2013, 24, 88-96. [CrossRef] [PubMed]

73. Kolodziejczyk-Czepas, J.; Wachowicz, B.; Moniuszko-Szajwaj, B.; Kowalska, I.; Oleszek, W.; Stochmal, A. Antioxidative effects of extracts from trifolium species on blood platelets exposed to oxidative stress. J. Physiol. Biochem. 2013, 69, 879-887. [CrossRef] [PubMed]

74. Yen, G.C.; Lai, H.H. Inhibition of reactive nitrogen species effects in vitro and in vivo by isoflavones and soy-based food extracts. J. Agric. Food Chem. 2003, 51, 7892-7900. [CrossRef] [PubMed]

75. Ma, X.; Jiang, Z.; Zhang, J.; Hu, Y.; Gao, K.; Wang, L.; Yang, X. Isoflavone ameliorates $\mathrm{H}_{2} \mathrm{O}_{2}$ induced injury by activating the antioxidant system of sow mammary gland cell. Nat. Sci. 2015, 7, 571.

76. Jin, L.; Zhao, X.; Qin, Y.; Zhu, W.; Zhang, W.; Liu, A.; Luo, Z. Soy isoflavones protect against $\mathrm{H}_{2} \mathrm{O}_{2}$-induced injury in human umbilical vein endothelial cells. Mol. Med. Rep. 2015, 12, 4476-4482. [CrossRef] [PubMed] 
77. Mann, G.E.; Bonacasa, B.; Ishii, T.; Siow, R.C. Targeting the redox sensitive nrf2-keap1 defense pathway in cardiovascular disease: Protection afforded by dietary isoflavones. Curr. Opin. Pharmacol. 2009, 9, 139-145. [CrossRef] [PubMed]

78. Zhai, X.; Lin, M.; Zhang, F.; Hu, Y.; Xu, X.; Li, Y.; Liu, K.; Ma, X.; Tian, X.; Yao, J. Dietary flavonoid genistein induces nrf2 and phase ii detoxification gene expression via erks and pkc pathways and protects against oxidative stress in caco-2 cells. Mol. Nutr. Food Res. 2013, 57, 249-259. [CrossRef] [PubMed]

79. Blay, M.; Espinel, A.; Delgado, M.; Baiges, I.; Blade, C.; Arola, L.; Salvado, J. Isoflavone effect on gene expression profile and biomarkers of inflammation. J. Pharm. Biomed. Anal. 2010, 51, 382-390. [CrossRef] [PubMed]

80. Ji, G.; Zhang, Y.; Yang, Q.; Cheng, S.; Hao, J.; Zhao, X.; Jiang, Z. Genistein suppresses lps-induced inflammatory response through inhibiting $\mathrm{nf}-\mathrm{kb}$ following amp kinase activation in raw 264.7 macrophages. PLoS ONE 2012, 7, e53101. [CrossRef] [PubMed]

81. Gao, Y.; Fang, L.; Liu, F.; Zong, C.; Cai, R.; Chen, X.; Qi, Y. Suppressive effects of irisflorentin on lps-induced inflammatory responses in raw 264.7 macrophages. Exp. Biol. Med. 2014, 239, 1018-1024. [CrossRef] [PubMed]

82. Satsu, H.; Hyun, J.S.; Shin, H.S.; Shimizu, M. Suppressive effect of an isoflavone fraction on tumor necrosis factor- $\alpha$-induced interleukin-8 production in human intestinal epithelial caco-2 cells. J. Nutr. Sci. Vitaminol. 2009, 55, 442-446. [CrossRef] [PubMed]

83. Morimoto, M.; Watanabe, T.; Yamori, M.; Takebe, M.; Wakatsuki, Y. Isoflavones regulate innate immunity and inhibit experimental colitis. J. Gastroenterol. Hepatol. 2009, 24, 1123-1129. [CrossRef] [PubMed]

84. Lesinski, G.B.; Reville, P.K.; Mace, T.A.; Young, G.S.; Ahn-Jarvis, J.; Thomas-Ahner, J.; Vodovotz, Y.; Ameen, Z.; Grainger, E.; Riedl, K.; et al. Consumption of soy isoflavone enriched bread in men with prostate cancer is associated with reduced proinflammatory cytokines and immunosuppressive cells. Cancer Prev. Res. 2015, 8 , 1036-1044. [CrossRef] [PubMed]

85. De Paula, M.L.; Rodrigues, D.H.; Teixeira, H.C.; Barsante, M.M.; Souza, M.A.; Ferreira, A.P. Genistein down-modulates pro-inflammatory cytokines and reverses clinical signs of experimental autoimmune encephalomyelitis. Int. Immunopharmacol. 2008, 8, 1291-1297. [CrossRef] [PubMed]

86. Yoo, N.Y.; Jeon, S.; Nam, Y.; Park, Y.J.; Won, S.B.; Kwon, Y.H. Dietary supplementation of genistein alleviates liver inflammation and fibrosis mediated by a methionine-choline-deficient diet in $\mathrm{db} / \mathrm{db}$ mice. J. Agric. Food Chem. 2015, 63, 4305-4311. [CrossRef] [PubMed]

87. Langenbach, R.; Morham, S.G.; Tiano, H.F.; Loftin, C.D.; Ghanayem, B.I.; Chulada, P.C.; Mahler, J.F.; Lee, C.A.; Goulding, E.H.; Kluckman, K.D. Prostaglandin synthase 1 gene disruption in mice reduces arachidonic acid-induced inflammation and indomethacin-induced gastric ulceration. Cell 1995, 83, 483-492. [CrossRef]

88. Kuehl, F.A.; Egan, R.W. Prostaglandins, arachidonic acid, and inflammation. Science 1980, $210,978-984$. [CrossRef] [PubMed]

89. Vane, J.R.; Mitchell, J.A.; Appleton, I.; Tomlinson, A.; Bishop-Bailey, D.; Croxtall, J.; Willoughby, D.A. Inducible isoforms of cyclooxygenase and nitric-oxide synthase in inflammation. Proc. Natl. Acad. Sci. USA 1994, 91, 2046-2050. [CrossRef] [PubMed]

90. Xiang, B.; Zhang, G.; Guo, L.; Li, X.-A.; Morris, A.J.; Daugherty, A.; Whiteheart, S.W.; Smyth, S.S.; Li, Z. Platelets protect from septic shock by inhibiting macrophage-dependent inflammation via the cyclooxygenase 1 signalling pathway. Nat. Commun. 2013, 4, 2657. [CrossRef] [PubMed]

91. Middleton, E., Jr.; Kandaswami, C.; Theoharides, T.C. The effects of plant flavonoids on mammalian cells: Implications for inflammation, heart disease, and cancer. Pharmacol. Rev. 2000, 52, 673-751. [PubMed]

92. Dharmappa, K.K.; Mohamed, R.; Shivaprasad, H.V.; Vishwanath, B.S. Genistein, a potent inhibitor of secretory phospholipase a2: A new insight in down regulation of inflammation. Inflammopharmacology 2010, 18, 25-31. [CrossRef] [PubMed]

93. Ximenes, R.M.; Rabello, M.M.; Araújo, R.M.; Silveira, E.R.; Fagundes, F.H.; Diz-Filho, E.; Buzzo, S.C.; Soares, V.C.; Toyama, D.D.O.; Gaeta, H.H. Inhibition of neurotoxic secretory phospholipases a2 enzymatic, edematogenic, and myotoxic activities by harpalycin 2, an isoflavone isolated from harpalyce brasiliana benth. Evid. Based Complement. Altern. Med. 2012, 2012. [CrossRef] [PubMed]

94. Suleyman, H.; Demircan, B.; Karagoz, Y. Anti-inflammatory and side effects of cyclooxygenase inhibitors. Pharmacol. Rep. 2007, 59, 247-258. [PubMed] 
95. Vera, R.; Galisteo, M.; Villar, I.C.; Sánchez, M.; Zarzuelo, A.; Pérez-Vizcaíno, F.; Duarte, J. Soy isoflavones improve endothelial function in spontaneously hypertensive rats in an estrogen-independent manner: Role of nitric-oxide synthase, superoxide, and cyclooxygenase metabolites. J. Pharmacol. Exp. Ther. 2005, 314, 1300-1309. [CrossRef] [PubMed]

96. Ahmad, A.; Ramasamy, K.; Jaafar, S.M.; Majeed, A.B.; Mani, V. Total isoflavones from soybean and tempeh reversed scopolamine-induced amnesia, improved cholinergic activities and reduced neuroinflammation in brain. Food Chem. Toxicol. Int. J. Publ. Br. Ind. Biol. Res. Assoc. 2014, 65, 120-128. [CrossRef] [PubMed]

97. Lau, T.Y.; Leung, L.K. Soya isoflavones suppress phorbol 12-myristate 13-acetate-induced cox-2 expression in mcf-7 cells. Br. J. Nutr. 2006, 96, 169-176. [CrossRef] [PubMed]

98. Li, Y.S.; Wu, L.P.; Li, K.H.; Liu, Y.P.; Xiang, R.; Zhang, S.B.; Zhu, L.Y.; Zhang, L.Y. Involvement of nuclear factor kappab (nf-kappab) in the downregulation of cyclooxygenase-2 (cox-2) by genistein in gastric cancer cells. J. Int. Med. Res. 2011, 39, 2141-2150. [CrossRef] [PubMed]

99. Mahesha, H.; Singh, S.A.; Rao, A.A. Inhibition of lipoxygenase by soy isoflavones: Evidence of isoflavones as redox inhibitors. Arch. Biochem. Biophys. 2007, 461, 176-185. [CrossRef] [PubMed]

100. Mascayano, C.; Espinosa, V.; Sepúlveda-Boza, S.; Hoobler, E.K.; Perry, S.; Diaz, G.; Holman, T.R. Enzymatic studies of isoflavonoids as selective and potent inhibitors of human leukocyte 5-lipo-oxygenase. Chem. Biol. Drug Des. 2015, 86, 114-121. [CrossRef] [PubMed]

101. Mascayano, C.; Espinosa, V.; Sepúlveda-Boza, S.; Hoobler, E.K.; Perry, S. In vitro study of isoflavones and isoflavans as potent inhibitors of human 12-and 15-lipoxygenases. Chem. Biol. Drug Des. 2013, 82, 317-325. [CrossRef] [PubMed]

102. Moncada, S.; Palmer, R.; Higgs, E. Nitric oxide: Physiology, pathophysiology, and pharmacology. Pharmacol. Rev. 1991, 43, 109-142. [PubMed]

103. Salvemini, D.; Kim, S.F.; Mollace, V. Reciprocal regulation of the nitric oxide and cyclooxygenase pathway in pathophysiology: Relevance and clinical implications. Am. J. Physiol. Regul. Integr. Comp. Physiol. 2013, 304, R473-R487. [CrossRef] [PubMed]

104. Sheu, F.; Lai, H.-H.; Yen, G.-C. Suppression effect of soy isoflavones on nitric oxide production in raw 264.7 macrophages. J. Agric. Food Chem. 2001, 49, 1767-1772. [CrossRef] [PubMed]

105. Park, J.-S.; Woo, M.-S.; Kim, D.-H.; Hyun, J.-W.; Kim, W.-K.; Lee, J.-C.; Kim, H.-S. Anti-inflammatory mechanisms of isoflavone metabolites in lipopolysaccharide-stimulated microglial cells. J. Pharmacol. Exp. Ther. 2007, 320, 1237-1245. [CrossRef] [PubMed]

106. Chinta, S.J.; Ganesan, A.; Reis-Rodrigues, P.; Lithgow, G.J.; Andersen, J.K. Anti-inflammatory role of the isoflavone diadzein in lipopolysaccharide-stimulated microglia: Implications for Parkinson's disease. Neurotox. Res. 2013, 23, 145-153. [CrossRef] [PubMed]

107. Nakaya, M.; Tachibana, H.; Yamada, K. Isoflavone genistein and daidzein up-regulate lps-induced inducible nitric oxide synthase activity through estrogen receptor pathway in raw264. 7 cells. Biochem. Pharmacol. 2005, 71, 108-114. [CrossRef] [PubMed]

108. Valachovicova, T.; Slivova, V.; Bergman, H.; Shuherk, J.; Sliva, D. Soy isoflavones suppress invasiveness of breast cancer cells by the inhibition of $\mathrm{nf}-\mathrm{kb} / \mathrm{ap}-1-d e p e n d e n t$ and-independent pathways. Int. J. Oncol. 2004, 25, 1389-1395. [CrossRef] [PubMed]

109. Pereira, S.G.; Oakley, F. Nuclear factor-kappab1: Regulation and function. Int. J. Biochem. Cell Biol. 2008, 40, 1425-1430. [CrossRef] [PubMed]

110. Barnes, P.J.; Karin, M. Nuclear factor-kappab: A pivotal transcription factor in chronic inflammatory diseases. N. Engl. J. Med. 1997, 336, 1066-1071. [PubMed]

111. Yang, F.; Tang, E.; Guan, K.; Wang, C.Y. Ikk beta plays an essential role in the phosphorylation of rela/p65 on serine 536 induced by lipopolysaccharide. J. Immunol. 2003, 170, 5630-5635. [CrossRef] [PubMed]

112. Chen, Y.; Vallee, S.; Wu, J.; Vu, D.; Sondek, J.; Ghosh, G. Inhibition of nf-kappab activity by ikappabbeta in association with kappab-ras. Mol. Cell. Biol. 2004, 24, 3048-3056. [CrossRef] [PubMed]

113. Davis, J.N.; Kucuk, O.; Djuric, Z.; Sarkar, F.H. Soy isoflavone supplementation in healthy men prevents nf-kb activation by tnf- $\alpha$ in blood lymphocytes. Free Radic. Biol. Med. 2001, 30, 1293-1302. [CrossRef]

114. Kim, J.W.; Jin, Y.C.; Kim, Y.M.; Rhie, S.; Kim, H.J.; Seo, H.G.; Lee, J.H.; Ha, Y.L.; Chang, K.C. Daidzein administration in vivo reduces myocardial injury in a rat ischemia/reperfusion model by inhibiting $\mathrm{nf}-\mathrm{kb}$ activation. Life Sci. 2009, 84, 227-234. [CrossRef] [PubMed] 
115. Lu, H.; Shi, J.-X.; Zhang, D.-M.; Chen, H.-L.; Qi, M.; Yin, H.-X. Genistein, a soybean isoflavone, reduces the production of pro-inflammatory and adhesion molecules induced by hemolysate in brain microvascular endothelial cells. Acta Neurol. Belg. 2009, 109, 32. [PubMed]

116. Eo, H.; Ann, J.-Y.; Lim, Y. Dietary supplementation of genistein attenuates inflammatory responses and oxidative stress during cutaneous wound healing in diabetic mice. J. Agric. Sci. 2015, 7, 80. [CrossRef]

117. Hilakivi-Clarke, L.; Andrade, J.E.; Helferich, W. Is soy consumption good or bad for the breast? J. Nutr. 2010, 140, 2326S-2334S. [CrossRef] [PubMed]

118. Ravishankar, D.; Rajora, A.K.; Greco, F.; Osborn, H.M. Flavonoids as prospective compounds for anti-cancer therapy. Int. J. Biochem. Cell Biol. 2013, 45, 2821-2831. [CrossRef] [PubMed]

119. Boucher, B.A.; Cotterchio, M.; Anderson, L.N.; Kreiger, N.; Kirsh, V.A.; Thompson, L.U. Use of isoflavone supplements is associated with reduced postmenopausal breast cancer risk. Int. J. Cancer 2013, 132, 1439-1450. [CrossRef] [PubMed]

120. Yamamoto, S.; Sobue, T.; Kobayashi, M.; Sasaki, S.; Tsugane, S. Soy, isoflavones, and breast cancer risk in japan. J. Natl. Cancer Inst. 2003, 95, 906-913. [CrossRef] [PubMed]

121. Nagata, C.; Mizoue, T.; Tanaka, K.; Tsuji, I.; Tamakoshi, A.; Matsuo, K.; Wakai, K.; Inoue, M.; Tsugane, S.; Sasazuki, S. Soy intake and breast cancer risk: An evaluation based on a systematic review of epidemiologic evidence among the Japanese population. Jpn. J. Clin. Oncol. 2014, 44, 282-295. [CrossRef] [PubMed]

122. Chen, M.; Rao, Y.; Zheng, Y.; Wei, S.; Li, Y.; Guo, T.; Yin, P. Association between soy isoflavone intake and breast cancer risk for pre-and post-menopausal women: A meta-analysis of epidemiological studies. PLoS ONE 2014, 9, e89288. [CrossRef] [PubMed]

123. Mense, S.M.; Hei, T.K.; Ganju, R.K.; Bhat, H.K. Phytoestrogens and breast cancer prevention: Possible mechanisms of action. Environ. Health Perspect. 2008, 116, 426. [CrossRef] [PubMed]

124. Allred, C.D.; Allred, K.F.; Ju, Y.H.; Clausen, L.M.; Doerge, D.R.; Schantz, S.L.; Korol, D.L.; Wallig, M.A.; Helferich, W.G. Dietary genistein results in larger mnu-induced, estrogen-dependent mammary tumors following ovariectomy of sprague-dawley rats. Carcinogenesis 2004, 25, 211-218. [CrossRef] [PubMed]

125. Kijkuokool, P.; Parhar, I.S.; Malaivijitnond, S. Genistein enhances N-nitrosomethylurea-induced rat mammary tumorigenesis. Cancer Lett. 2006, 242, 53-59. [CrossRef] [PubMed]

126. Yang, Q.; Mas, A.; Elam, L.; Trevino, L.; Berry, T.; Walker, C.; Diamond, M.; Al-Hendy, A. Early life exposure to genistein permanently decreases myometrial DNA repair capacity, which may contribute to increased risk of uterine fibroid development. Fertil. Steril. 2015, 104, e30. [CrossRef]

127. Greathouse, K.L.; Bredfeldt, T.; Everitt, J.I.; Lin, K.; Berry, T.; Kannan, K.; Mittelstadt, M.L.; Ho, S.-M.; Walker, C.L. Environmental estrogens differentially engage the histone methyltransferase ezh2 to increase risk of uterine tumorigenesis. Mol. Cancer Res. 2012, 10, 546-557. [CrossRef] [PubMed]

128. Hsu, A.; Bray, T.M.; Helferich, W.G.; Doerge, D.R.; Ho, E. Differential effects of whole soy extract and soy isoflavones on apoptosis in prostate cancer cells. Exp. Biol. Med. 2010, 235, 90-97. [CrossRef] [PubMed]

129. Rietjens, I.M.; Sotoca, A.M.; Vervoort, J.; Louisse, J. Mechanisms underlying the dualistic mode of action of major soy isoflavones in relation to cell proliferation and cancer risks. Mol. Nutr. Food Res. 2013, 57, 100-113. [CrossRef] [PubMed]

130. Yellayi, S.; Naaz, A.; Szewczykowski, M.A.; Sato, T.; Woods, J.A.; Chang, J.; Segre, M.; Allred, C.D.; Helferich, W.G.; Cooke, P.S. The phytoestrogen genistein induces thymic and immune changes: A human health concern? Proc. Natl. Acad. Sci. USA 2002, 99, 7616-7621. [CrossRef] [PubMed]

131. Yellayi, S.; Zakroczymski, M.A.; Selvaraj, V.; Valli, V.E.; Ghanta, V.; Helferich, W.G.; Cooke, P.S. The phytoestrogen genistein suppresses cell-mediated immunity in mice. J. Endocrinol. 2003, 176, 267-274. [CrossRef] [PubMed]

132. Ebaid, H.M.; Elgawish, R.A.R.; Abdelrazek, H.M.; Gaffer, G.; Tag, H.M. Prenatal exposure to soy isoflavones altered the immunological parameters in female rats. Int. J. Toxicol. 2016. [CrossRef] [PubMed]

133. Portman, M.A. Kawasaki disease and soy: Potential role for isoflavone interaction with fc $\gamma$ receptors. Pediatr. Res. 2012, 73, 130-134. [CrossRef] [PubMed]

134. Chen, A.; Rogan, W.J. Isoflavones in soy infant formula: A review of evidence for endocrine and other activity in infants. Annu. Rev. Nutr. 2004, 24, 33-54. [CrossRef] [PubMed]

135. Andrade, J.E.; Ju, Y.H.; Baker, C.; Doerge, D.R.; Helferich, W.G. Long-term exposure to dietary sources of genistein induces estrogen-independence in the human breast cancer (mcf-7) xenograft model. Mol. Nutr. Food Res. 2015, 59, 413-423. [CrossRef] [PubMed] 
136. Woo, H.D.; Park, K.-S.; Ro, J.; Kim, J. Differential influence of dietary soy intake on the risk of breast cancer recurrence related to her2 status. Nutr. Cancer 2012, 64, 198-205. [CrossRef] [PubMed]

137. Lofamia, E.A.A.; Ramos, G.B.; Mamon, M.A.C.; Salido, F.M.; Su, G.S.; de Vera, M.P. Isoflavone maternal-supplementation during periconception period: Influence on the reproductive organs of the first generation (f1) murine weanling-stage offspring. Asian Pac. J. Reprod. 2014, 3, 268-274. [CrossRef]

138. Delclos, K.B.; Bucci, T.J.; Lomax, L.G.; Latendresse, J.R.; Warbritton, A.; Weis, C.C.; Newbold, R.R. Effects of dietary genistein exposure during development on male and female cd (sprague-dawley) rats. Reprod. Toxicol. 2001, 15, 647-663. [CrossRef]

139. Xiao, Y.; Mao, X.; Yu, B.; He, J.; Yu, J.; Zheng, P.; Huang, Z.; Chen, D. Potential risk of isoflavones: Toxicological study of daidzein supplementation in piglets. J. Agric. Food Chem. 2015, 63, 4228-4235. [CrossRef] [PubMed]

140. Ziberna, L.; Lunder, M.; Moze, S.; Vanzo, A.; Tramer, F.; Passamonti, S.; Drevensek, G. Acute cardioprotective and cardiotoxic effects of bilberry anthocyanins in ischemia-reperfusion injury: Beyond concentration-dependent antioxidant activity. Cardiovasc. Toxicol. 2010, 10, 283-294. [CrossRef] [PubMed]

141. Chen, W.; Lin, Y.C.; Ma, X.Y.; Jiang, Z.Y.; Lan, S.P. High concentrations of genistein exhibit pro-oxidant effects in primary muscle cells through mechanisms involving 5-lipoxygenase-mediated production of reactive oxygen species. Food Chem. Toxicol. 2014, 67, 72-79. [CrossRef] [PubMed]

(C) 2016 by the authors; licensee MDPI, Basel, Switzerland. This article is an open access article distributed under the terms and conditions of the Creative Commons Attribution (CC-BY) license (http://creativecommons.org/licenses/by/4.0/). 